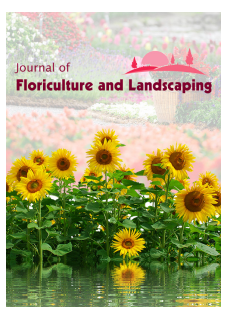

ISSN: $2663-6050$

Received: November 29, 2018 Accepted: December 30, 2018 Published: December 31, 2018

*Corresponding Author: G. F. Akomolafe Email: gfakomolafe@yahoo. com

\title{
Phytoremediation and agricultural productivity - A mini review
}

\author{
G. F. Akomolafe ${ }^{1 *}$, K. C. Onwusiri ${ }^{2}$, F. A. Adokpa' \\ 'Department of Botany, Federal University Lafia, PMB 146, Lafia, Nigeria, ${ }^{2}$ National Environmental Standards and \\ Regulations Enforcement Agency (NESREA), Akwa-lbom State Field office, Uyo, Nigeria
}

\begin{abstract}
The productivity of Agricultural land has reduced drastically particularly in highly industrialized and oil producing Countries as a result of incessant discharge of toxic compounds from many human activities into the environment. Plants are described as effective organisms for remediating polluted environment mainly due to their exceptional biological features. Some of the popular, modern and commercialized processes that have been used over the years in decontaminating polluted sites are not eco-friendly and are expensive. This is why more emphasis is laid on less-expensive and eco-friendly technique which uses green plants called phytoremediation. This review described phytoextraction, phytostabilization, rhizofiltration, phytodegradation and phytovolatilization as various techniques of phytoremediation with examples of plants that are used for this purpose. It also clearly describes healthy soil as promoter of crops yield and improving the lively hood of man and other organisms in the ecosystem.
\end{abstract}

KEYWORDS: Agriculture, contamination, environmetal pollution, hyperaccumulator, phytoremediation

\section{INTRODUCTION}

The removal of chemical substances mainly heavy metals from polluted soil has been the challenge of many developed and oil producing countries. Most Agricultural land and aquatic bodies have been polluted by exploration and spillage of petroleum resources which led to land used for Agricultural purposes becoming more destructive including the creeks and fishing waters. Man is perpetually exposed to heavy metals in so many ways due to anthropogenic activities. So many chemical producing industries have contributed to release of considerable amount of dangerous chemical wastes into the aquatic bodies close to them. When these chemicals move to ecosystem they result bioaccumulation of such poisons in organisms which can then be transferred to other living organisms via the food chain [1]. Some heavy metals have been identified as major environmental pollutants across the world [2].

Soil has been described as the basis of our agricultural resources. It is also a promoter of food security, global economy and environmental quality. Soil has been progressively contaminated with various environmental pollutants because of increasing industrialization. This has posed serious threats to ecosystems and human health. Therefore managing and remediating such soil has become highly imperative. Some of the popular, modern and commercialized processes that have been used over the years in decontaminating polluted sites are not eco-friendly and are expensive [3]. Pollution is a global concern emanating from anthropogenic activities such as mining, smelting, intensive agriculture, power transmission, oil exploration, sludge dumping and melting operations. However the demands for global economic and industrial development is more than seeking for healthy and safe environments [4].

For many years ago, increasing concentrations of heavy metals which are regarded as harmful substances have gained so much attention by environmental scientists. These elements have atomic weights ranging between 63.546 to 200.590 and a specific gravity greater than 5.0. They are toxic, non-biodegradable and have biomagnified characteristics [5, 6]. According to the earlier report [4], pollution creates serious casualties again and again, thus environmental quality enhancing is a necessary for a sustainable development.

\section{REMEDIATION TECHNIQUES}

There are different techniques used in the decontamination of soil and water polluted with environmental pollutants. These include the followings:

\section{Physical Remediation Techniques}

Physical Remediation Techniques use modern techniques for cleaning soil. These include excavation, capping with geotextiles, washing of soil and extraction of soil vapor [7]. 


\section{Bioremediation}

Bioremediation which is biological remediating technique involving the use of microorganisms to remove or neutralize pollutants from a polluted site. Bioremediation may occur naturally on its own or be influenced through the addition of organic materials such as fertilizers, oxygen, etc., which stimulate growth of microorganisms within the medium. Bioremediation could be microbial remediation or compost remediation. This technique can be very effective in the treatment of both organic and inorganic compounds. The cost of achieving this is relatively low within a short period of time [7].

\section{Phytoremediation}

Phytoremediation which involves the use of green plants in cleaning soils and water contaminated with different environmental pollutants. Recently the used of plants to clean such soil has been on investigation by several scientist in order to identify plants that can enhance this process. In view of this, different plants species have been study for their ability to detoxify heavy metals and other pollutants at different $\mathrm{pH}$ range. We shall discuss this fully below.

\section{PHYTOREMEDIATION}

It has been earlier established that the current techniques of remediating contaminated environment are very costly and not eco-friendly. In as much as metals cannot be degraded unlike organic compounds, therefore there is need for them to be immobilized in order to be effectively detoxified. Phytoremediation has been termed by various authors as green remediation or vegetative remediation which is considered a remediation technology that uses vegetation together with microflora and fauna, soil amendments and various techniques to detoxify contaminants in the soil [8, 9]. Phytoremediation usually use both natural and genetically engineered plants for its purpose. Plants are described as very effective in remediating polluted environment mainly due to their exceptional biological features. All plants root have the natural ability to accumulate essential metal such as $\mathrm{Co}, \mathrm{Mg}, \mathrm{Cu}, \mathrm{Pb}$ etc. from soil solution, behaving as natural phytoremediates. In doing this, plants needs different concentration of these metals for their growth and developments. Non-essential heavy metals are those, which are not primarily important in the metabolic activities of plants. Examples include $\mathrm{Cd}, \mathrm{Hg}$ and As $[10,11,12]$. Essential heavy metals are required for all metabolic activities of plants like Mn, Fe, Ni, Cu and Zn [13]. All these micronutrients can be harmful to plants and disrupt a lot of physiological processes in plants whenever they are present in excess [14]. Phytoremediation can only be successful whenever plants that can accumulate exceeding amount of these heavy metals in their biomass are chosen and used.

\section{DIFFERENT PHYTOREMEDIATION METHODS}

There are a lot of methods that have been reported in using plants to remediate polluted sites. For the purpose of this review, the common ones such as phytoextraction, phytostabilization, rhizofiltration, phytodegradation and phytovolatilization will be discussed.

\section{Phytoextraction}

Phytoextraction also known as phytoaccumulation can be described as a process in which contaminants of any form are directly absorbed from the environment into the tissues of plants. It can be effected by making use of hyperaccumulator plant species of the specific contaminant. These hyperaccumulators are capable of absorbing an exceptional amount of these contaminants without affecting their growth and other physiological activities. Many research works have reported the ability of some ferns particularly Pteris vittata commonly known as the Chinese ladder brake fern in hyperaccumulating arsenic $[15,16]$. This plant has been known to accumulate exceptional amount of the heavy metal in both above ground and below ground biomass with no phytotoxicity symptoms [17].

\section{Phytostabilization}

Phytostabilization entails the using plants to render plants inactive in the soil and groundwater which can be achieved mainly through adsorption onto roots or precipitation within the root zone. It has been reported to be effective in remediating a lot of heavy metals such as $\mathrm{Pb}, \mathrm{As}, \mathrm{Cd}, \mathrm{Cr}, \mathrm{Cu}$ and $\mathrm{Zn}$ [18]. This method does not alter any of the soil physical and biological properties and is therefore referred to as a low impact site rehabilitation technique [19].

\section{Rhizofiltration}

Rhizofiltration is concerned with using plants to absorb, concentrate, and precipitate contaminants from polluted aqueous sources in their roots. It is effective for precipitating metals that are retained within roots such as $\mathrm{Pb}, \mathrm{Ni}, \mathrm{Zn}$, and Cr [20]. Rhizofiltration has also been described primarily as a technique used to remediate aquatic sites with low concentrations of contaminants [21, 22, 20].

\section{Phytodegradation}

Phytodegradation otherwise called phytotransformation involves use of plants particularly the roots of plant in alliance with microorganisms to breakdown complex organic and toxic compounds into simple and non-toxic ones [23]. Some of the plants produce several enzymes that are used in decontaminating polluted sites. Examples of the enzymes include dehalogenase and oxygenase [24].

\section{Phytovolatalization}

Phytovolatalization is using plants in absorption of pollutants from the polluted environment, changing to volatile forms and releasing to atmosphere $[25,20]$. Phytovolatilization takes place as plants are in the period of growth whereby they uptake dissolved substances containing these contaminants from the soil. 


\section{PLANTS USED FOR PHYTOREMEDIATION}

Some species of angiosperms have potential for remediation of soils polluted with heavy metals [26]. Also, a lot of pteridophytes have been assessed for ability to remediate heavy metal contaminated sites and they have been reported to be very good phytoremediators due to their inherent biological abilities [16]. Below is a summary of several plants used for phytoremediation (Table 1).

\section{MECHANISM OF PHYTOREMEDIATION}

Plants have evolved several mechanisms for engaging in the process of phytoremediation. Plants absorb metals from the polluted soil during the period of growth. Plant-metal uptake can be passive in which metal ions pass through the cell wall of the root cells. It may also be active by which metal ions move through the cells membrane of the root [27]. There are some membrane proteins in plants that recognize the chemical nature of essential metals and then bind the metals for uptake and transport [28]. Some of these metal ions are similar in chemical composition in such a way that the proteins consider them as the same.

\section{HYPERACCUMULATORS}

About 400 plant species belonging to 45 plant families have been reported as hyperaccumulators of heavy metals $[29,30]$. Hyperaccumulation is the uptake and sequestration of extraordinary amount of an element in shoots under field conditions [31]. The followings have been reported as thresholds for these different heavy metals; $100 \mu \mathrm{g} / \mathrm{g}$ for cadmium, $1000 \mu \mathrm{g} / \mathrm{g}$ for cobalt, copper, nickel and lead while $10,000 \mu \mathrm{g} / \mathrm{g}$ is for manganese and zinc. The metals are stored

Table 1: checklist of some plants used for remediation with the respective metals

\begin{tabular}{lllc}
\hline S/N & Name of plant & Metal (s) & Source (s) \\
\hline 1 & Jatropha curcas & Trace and heavy metals & {$[26]$} \\
2 & Dodonaea viscosa & Trace and heavy metals & {$[26]$} \\
3 & Cassia auriculata & Trace and heavy metals & {$[26]$} \\
4 & Zea mays & Trace and heavy metals & {$[37,38]$} \\
5 & Sorghum bicolor & Trace and heavy metals & {$[37]$} \\
6 & Medicago sativa & Trace and heavy metals & {$[37]$} \\
7 & Thlaspi caerulescens & Cd, Zn & {$[29]$} \\
8 & Ipomea alpine & Cu & {$[29]$} \\
9 & Haumaniastrum robertii & $\mathrm{Co}$ & {$[29]$} \\
10 & Astragalus racemosus & $\mathrm{Se}$ & {$[29]$} \\
11 & Sebertia acuminate & $\mathrm{Ni}$ & {$[29]$} \\
12 & Salix viminalis & Trace and heavy metals & {$[38]$} \\
13 & Brassica juncea & $\mathrm{Cd}$ & {$[38]$} \\
14 & Helianthus annuus & $\mathrm{Cu}, \mathrm{Cd}, \mathrm{Cr}, \mathrm{Ni}, \mathrm{Pb}$ & {$[38]$} \\
& & and Zn & {$[39]$} \\
15 & Thlaspi caerulescens & $\mathrm{Zn}$ & {$[39]$} \\
16 & Nicotiana tabacum & $\mathrm{Cd}$ & {$[17,15]$} \\
17 & Pteris vittata & $\mathrm{As}$ & {$[40]$} \\
18 & Limnocharis flava & $\mathrm{Cd}$ & {$[41]$} \\
19 & Hopea odorata & $\mathrm{Cd}$ & {$[41]$} \\
20 & Intsia palembanica & $\mathrm{Cd}$ & {$[41]$} \\
21 & Acacia mangium & $\mathrm{As}$ & {$[42]$} \\
22 & Elsholtzia splendens & $\mathrm{Cu}$ & $\mathrm{Cd}$ \\
23 & Glycine max & &
\end{tabular}

J Floricult Landsc • 2018 • Vol 4 in less sensitive organs such as vacuoles, cell walls, epidermal cells and trichomes soon after uptake [32]. As one of the ways of restoring heavy metals - polluted soils and water to manageable level, some angiosperms whose rhizospheres are able to accumulate heavy metals from the soil are also used. [33] reported that Mucuna jaspodea, M. vereacruz and $M$. ghana accumulated lead, nickel and copper in their vegetative parts. It was reported that the species had strong tendencies to accumulate $\mathrm{Cu}$ and $\mathrm{Zn}$ [34].

\section{RELEVANCE OF PHYTOREMEDIATION TO AGRICULTURE}

Healthy soil is a major requirement for agricultural production, food production and boosting of country's economy. Parts of the requirements needed by plants for survival are air, sun, water, and soil. The quality of soil is more important than quantity. The presence of essential elements along with water, air, and soil microorganisms that break down organic matter in the soil makes the soil healthy, rich and fertile. In a way of improving yields of crops planted in polluted soil, the regaining of the soil fertility upon pollution is very important. It has been reported that if an agricultural soil is polluted, the plants cultivated on that particular soil will be high. Therefore, it is important to ensure that soil to be used for cultivating edible crop is in good status [35]. Also, if high and healthy crop yields are to be maintained, phytoremediation techniques together with composting (addition of organic or in organic manure to the soil) has to be employed in order to fix nitrogen, phosphorus, potassium and other nutrients. Phytoremediation helps in maintaining and improving soil fertility by providing the basic nutrient requirements of the crop and by providing an enabling environment for absorption of water and nutrients by plant roots. It also enhances the activities of soil organisms such as decomposition of organic matters which in turn release nutrients to plants. According to [30], most of the polluted agricultural soils contain hardy and tolerant weed species which can also assist in remediation of these contaminants and thereby disallowing them from passing into the food web.

Phytoremediation and Agriculture are inseparable entities. Phytoremediation is in actual fact an agricultural practice which can only be successful if only appropriate method is put employed at the site. There are some Agricultural practices that have been reported to be useful in enhancing phytoremediation potentials of several plants. Soil fertilization is one of those Agricultural practices. For instance, application of Phosphorus fertilizer will increase biomass production [36]. Another agronomic method in phytoremediation is crop rotation. It is advised that crops used for phytoremediation must be rotated because of the abundance of weeds, predators, and diseases, which may result in considerable reduction of yield [29]. Furthermore, Weed control and irrigation are additional agricultural practices which can enhance phytoremediation. Weeds can be controlled mechanically or chemically through the use of herbicide either as pre-emergent or post-emergent of phytoremediators. Pre-emergent herbicides application ensures good weed control, quick growth and establishment 
of selected phytoremediators while post-emergent herbicides deals with weeds that occur after the phytoremediators have been established. Also, maintaining an adequate soil moisture through irrigation and other means is important since this largely regulates the metal uptake into roots [29].

\section{CONCLUSION}

Restoring fertility to agricultural land previously polluted by heavy metals and other toxic pollutants is very imperative. In order to ensure a sustainable agricultural system, polluted agricultural resources must be remediated and well managed to satisfy human needs and the environment. Healthy soil promote crops yield and better the lively hood of man and other organisms in the ecosystem.

\section{REFERENCES}

1. Dembitsky V. Natural occurrence of arseno compounds in plants, lichens, fungi, algal species, and microorganisms. Plant Science. 2003; 165:1177-1192.

2. Manohar S, Jadia CD, Fulekar MH. Impact of ganesh idol immersion on water quality. Indian Journal of Environmental Protection. 2006; 27(3):216-220.

3. Lundstedt S. Analysis of PAHs and their transformation products in contaminated soil and remedial processes. Akademisk avhandling Solfjädern Offset AB Umeå. 2003.

4. Jadia CD, Fulekar MH. Phytotoxicity and remediation of heavy metals by fibrous root grass (sorghum). Journal of Applied Biology. 2008; 10:491-499.

5. Adepoju-Bello AA, Ojomolade OO, Ayoola GA, Coker AAB. Quantitative analysis of some toxic metals in domestic water obtained from Lagos metropolis. The Nigerian Journal of Pharmacy. 2009; 42(1):57-60.

6. Momodu M, Anyakora C. Heavy Metal Contamination of Groundwater: The Surulere Case Study. Research Journal of Environment and Earth Science. 2010;2(1):39-43.

7. Alexandra H, Patricia M, Edmund M, Jane R, Gloria S, Walsh H. Soil Contamination and Urban Agriculture. A practical guide to soil contamination issues for individuals and groups. 2002.

8. Vyslouzilova M, Tlustos P, Szakova J, Pavlikova D. As, Cd, Pb and Zn uptake by Salix spp. Clones grown in soils enriched by high loads of these elements. Plant Soil Environment. 2003;49:191-196.

9. Helmisaari HS, Salema M, Derome J, Kiikkila O, Uhlig C, Nieminen TM. Remediation of heavy metal-contaminated forest soil using recycled organic matter and native woody plants. Journal of Environmental Quality. 2007;36:1145-1153.

10. Suzuki N, Sano HKN. Screening of cadmium-responsive genes in Arabidopsis thaliana, Plant Cell Environment 2001;24:1177-1188.

11. Bidar G, Garcon G, Pruvot C, Waterlot C, Douay F, Shirali P. "The phytomanagement of soils highly contaminated by metals: Use of Trifolium repens and Lolium perenne as experimental model", Difpolmine Conference, 12-14 December, Le Corum-MontpellierFrance;2006.

12. Peng KJ, Luo CL, Chen YH, Wang GP, Li XD, Shen ZG. Cadmium and other metal uptake by Lobelia chinensis and Solanum nigrum from contaminated soils. Environmental Contamination and Toxicology. 2009; 83:260-264

13. Gohre V, Paszkowski U. "Contribution of the arbuscular mycorrhizal symbiosis to heavy metal phytoremediation", Plantae. 2006; 223:1115-1122.

14. Williams GM, Kroes R, Munro IC. Safety Evaluation and Risk Assessment of the Herbicide Roundup1 and Its Active Ingredient, Glyphosate, for Humans Regulatory. Toxicology and Pharmacology. 2000;31:117-165

15. Ma LQ, Komar KM, Tu C, Zhang W, Cai Y, Kennelley ED. A fern that hyperaccumulates arsenic. Nature. 2001;409:579-579.

16. Akomolafe GF, Dedeke OA, Sirajo SA. Tolerance mechanisms in pteridophytes (ferns) and their use as remediators of heavy metal contaminated sites. In: E.H. Kwon-Ndung, D. M. Ogah and A. Yakubu (eds), Proceedings of $37^{\text {th }}$ Annual Conference of Genetics Society of Nigeria, Lafia; 2013.

17. Oloyede FA, Akomolafe GF, Odiwe IA. Arsenic hyperaccumulation and Phytoremediation potentials of Pteris vittata and P. ensiformis (ferns) in Nigeria. Acta Botanica Hungarica. 2013;55(3-4):377-384.

18. Alvarenga P, Gonçalves AP, Fernandes RM, de Varennes A, Vallini G, Duarte E, Cunha-Queda AC. Organic residues as immobilizing agents in aided phytostabilization: (I) Effects on soil chemical characteristics. Chemosphere. 2009;74(10):1292-1300.

19. Chhotu DJ, Fulekar MN. The Application of Vermic Compost to Remove Zinc Cadmium, Copper, Nickel 728 Influence of Zinc. and Lead by Sunflower Plant. Journal of Environmental Biota and Management. 2008;7(5):547-558.

20. United States Protection Agency (USPA). Introduction to Phytoremediation. EPA 600/R-99/107. U.S. Environmental Protection Agency, Office of Research and Development, Cincinnati, OH; 2000.

21. Ensley BD. "Rationale for the Use of Phytoremediation." Phytoremediation of toxic metals: Using plants to clean-up the environment. John Wiley Publishers: New York; 2000.

22. Raskin I, Ensley BD. Phytoremediation of Toxic Metals: Using Plants to Clean Up the Environment. John Wiley \& Sons, Inc., New York; 2000.

23. Garbisu C, Alkorta I. Phytoextraction: a cost-effective plant-based technology for the removal of metals from the environment. Bioresource Technology. 2001;77:229-236.

24. Prasad MNV, Freitas H. Metal hyperaccumulation in plants-Biodiversity prospecting for phytoremediation technology. Electronic Journal of Biotechnology. 2003;6:275-321

25. Karami A, Shamsuddin ZH. Phytoremediation of heavy metals with several efficiency enhancer methods. African Journal of Biotechnology. 2010;9(25):3689-3698.

26. Nagaraju A, Karimulla S. Accumulation of elements in plants and soils in and around Nellore mica belt, Andhra Pradesh, India: a biogeochemical study. Environmental Geology. 2002;41(7):852-860.

27. Pilon-Smits E. Phytoremediation, Annual Review of Plant Biology. 2005;56:15-39.

28. Axelsen KB, Palmgren MG. Inventory of the superfamily of P-type ion pumps in Arabidopsis. Plant Physiology. 2001;126:696-706.

29. Lasat MM. Phytoextraction Of Metals from Contaminated Soil: A Review of Plant/Soil/Metal Interaction and Assessment of Pertinent Agronomic Issues. Journal of Hazardous Substance and Research. 2000;2:1-5.

30. Ghosh M, Singh SP. A review on phytoremediation of heavy metals and utilization of its byproducts. Applied ecology and environmental Research. 2005;3(1):1-18

31. Pollard G. Metal hyperaccumulation: a model system for evolutionary studies. New Phytology. 2000;146:179-181.

32. Boyd R., Wall MA, Watkins JE. Correspondence between nickel tolerance and hyperaccumulation in Streptanthus (Brassicaceae). Madrono. 2000;47:97-105.

33. Omosun G, Edeoga HO, Markson AA, Madunagu BE. Uptake of lead, nickel and copper by three Mucuna species. International Journal of Current Research. 2010;4:098-103.

34. Mahmood S, Mahmood A, Hussain Z, Athar M. Germination and seedling growth of Zea mays under varying levels of copper and zinc. International Journal of Environmental Science and Technology. 2005;2(3):269- 274.

35. Agbogidi OM, Enujeke EC. Heavy metals content of three common vegetables sold in markets of Asaba metropolis, Nigeria, Proceedings of the $45^{\text {th }}$ Annual Conference of the Agricultural Society of Nigeria held at Faculty of Agriculture Usmanu Danfodiyo University, Sokoto, Nigeria; 2011.

36. Chaney RL, Brown SL, Li YM, Angle JS, Stuczynski TI, Daniels WL, Henry CL, Siebelec G, Malik M, Ryan JA, Compton H. "Progress in risk assessment for soil metals, and in-situ remediation and phytoextraction of metals from hazardous contaminated soils. U.SEPA "Phytoremediation: State of Science," Boston, MA; 2000.

37. Vijayarengan P. Iron and manganese status of blackgram cultivars under nickel stress. Geobioscience. 2005;32:11-13.

38. Schmidt U. Enhancing Phytoextraction: The effects of chemical soil manipulation on mobility, plant accumulation, and leaching of heavy metals. Journal of Environmental Quality. 2003;32:1939-1954.

39. Gisbert C, Clemente R, Navarro-Avino J, Carlos C, Giner A, Serrano R, 
Walker DJ, Pilar MP. Tolerance and accumulation of heavy metals by Brassicaceae species grown in contaminated soils from Mediterranean regions of Spain. Environmental and Experimental Botany. 2006;56:19-26.

40. Abhilash P, Pandey VC, Srivastava P, Rakesh PS, Chandran S, Singh N, Thomas AP. Phytofiltration of cadmium from water by Limnocharis flava (L.) Buchenau grown in free-floating culture system. Journal of Hazardous Materials. 2009; 170(2-3): 791-797.

41. Ang LH, Tang LK, Hui TF, Ho WM, Theisera GW. Bioaccumulation of heavy metals by Acacia mangium, Hopea odorata, Intsia palembanica and Swietenia macrophylla grown on slime tailings. Project No. 05-0310-SF0038, Forest Research Institute Malaysia (FRIM), Malaysia; 2003.

42. Jiang LY, Yang XE, He ZL. Growth response and phytoextraction of copper at different levels in soils by Elsholtzia splendens. Chemosphere. 2004;55(9):1179-1187.

43. Murakami M, Ae N, Ishikawa S. Phytoextraction of cadmium by rice (Oryza sativa L.), soybean (Glycine max (L.) Merr.), and maize (Zea mays L.). Environmental Pollution. 2007;145(1):96-103. 